\title{
GOVERNMENT CANYON STATE NATURAL AREA: AN EMERGING MODEL FOR KARST MANAGEMENT
}

\section{George Veni}

Executive Director, National Cave and Karst Research Institute, 400-1 Cascades Avenue, Carlsbad, New Mexico

88220-6215 USA, gveni@nckri.org

\section{Abstract}

Government Canyon State Natural Area (GCSNA) is located on the northwest edge of San Antonio, Texas, USA. Ninety percent of the $47.04 \mathrm{~km}^{2}$ property is located on the recharge zone of the karstic Edwards (Balcones Fault Zone) Aquifer. Urban development is encroaching onto the Edwards Aquifer karst and threatening groundwater quality and karst ecosystems. GCSNA has served as a model for karst management by:

- defining existing resources;

- restoring impacted resources;

- monitoring and protecting groundwater quality and quantity by encompassing $62 \%$ of the $30.46-\mathrm{km}^{2}$ Government Canyon watershed on the Edwards Aquifer recharge and contributing zones, and over $23 \mathrm{~km}^{2}$ of adjacent karst watersheds;

- preserving the unique cave fauna;

- limiting all development to non-karst areas;

- using state-of-the-art construction techniques and infrastructure to minimize water and ecological impacts;

- monitoring land use conditions for an adaptive resource management plan; and

- establishing contiguous buffers around the core resource area.

This approach was made possible by designating GCSNA as a karst preserve in order to most effectively manage all of its resources. Karst attributes of GCSNA predominantly determine the location, type, magnitude, and management of its most significant natural and cultural resources. Federally listed endangered invertebrate species and the county's largest known bat population occur in its caves. Springs and deep canyons provide habitat for a diverse flora and fauna, including the endangered Golden-cheeked warbler. These springs and species, along with chert deposits and natural trails through rugged terrain, have supported human occupation since prehistoric times. Springflow and streamflow rapidly recharge the Edwards Aquifer to maintain this sole source system as a sustainable regional water supply. Partnerships with multiple agencies and volunteers have minimized individual costs, provided more thorough and complete assessment of karst resource issues, and developed public educational programs on the values of karst.

\section{Introduction}

Government Canyon State Natural Area (GCSNA) is located within the northwest limits of San Antonio, Texas, USA. It is a karst area that was planned for urban development but purchased by a partnership of three governmental agencies and two non-profit organizations. This arrangement was unprecedented for the state of Texas and established the first of many actions that would make GCSNA a model of how to best purchase, research, develop, and manage a property for natural resource protection. This paper first outlines the natural and cultural resources of GCSNA, then uses its history as a model example by which multi-disciplinary research and cooperation of several partners can be used for effective karst resource management.

\section{Natural and Cultural Resources: Description and Setting}

GCSNA encompasses $47.04 \mathrm{~km}^{2}$ in northwestern Bexar County at the southern edge of the Edwards Plateau. It is comprised of gently sloping karst ridge tops along its north, east, and west borders that slope steeply down to a nearly level valley floor that runs through the middle of the property. It ranges in elevation from $469 \mathrm{~m}$ above mean sea level near its northeast corner to $335 \mathrm{~m}$ where the valley's bed exits the south-central portion of the property.

The Balcones Escarpment, the topographic expression of the Balcones Fault Zone, cuts east-west across the southern edge of GCSNA. It separates the low-relief Gulf Coastal Plain from the ruggedly dissected Hill Country to the north, and marks the boundary where several geological, biological, and cultural zones meet, resulting in a high diversity of natural and cultural features. 


\section{GCSNA Geology}

Three Cretaceous age limestone formations crop out at GCSNA. See Barnes (1983) for a regional geologic map. The Glen Rose Formation, the oldest unit, is found along valley floors in the northern two-thirds of GCSNA. It is approximately $165 \mathrm{~m}$ thick with only the uppermost $30 \mathrm{~m}$ exposed. The Glen Rose is a series of hard limestone and dolomite beds interbedded with softer beds of clay and marl, which erode to create a stair-step topography. Dinosaur tracks are occasionally found in the limestone beds.

Above the Glen Rose is the Edwards Limestone Group, the most cavernous unit in the study area. Rose (1972) subdivided the Edwards into the Kainer Formation at the base, with ascending Basal Nodular, Dolomitic, Kirschberg, and Grainstone members, and the Person Formation at the top, with ascending Regional Dense, Collapsed, Leached, Marine, and Cyclic members. Maclay and Small (1984) included the Basal Nodular Member as the base of the Kainer. The Edwards is a hard, crystalline, and fossiliferous rock that forms most of the steep hills and cliffs that cover the northern two-thirds of GCSNA. Nearly all of the Edwards' 137 m thickness is exposed at GCSNA (Stein and Ozuna, 1995).

The third and youngest formation exposed is the Austin Chalk. It is a relatively soft unit, approximately $60 \mathrm{~m}$ thick, of which about the lowermost $20 \mathrm{~m}$ are exposed. It underlies the flat southern third of GCSNA.

The dominant geologic feature at GCSNA is the Miocene-age Balcones Fault Zone, a system of parallel to subparallel faults that locally trend northeast to southwest and drop down to the south and southeast. With $180 \mathrm{~m}$ of drop, the Haby Crossing Fault has the greatest displacement of any fault known in Bexar County. Where it crosses GCSNA it is marked by the Balcones Escarpment, a sudden rise in the land where the Austin Chalk meets the Edwards Limestone Formation. South of the fault, the Edwards and Glen Rose are buried below the Austin Chalk. North of the fault, the Austin Chalk has long ago been eroded from above those units.

Groundwater in the study area occurs in or is related to one or more of three aquifers: the Edwards Outlier Aquifer, Upper Trinity Aquifer, and Edwards (Balcones Fault Zone) Aquifer (hereafter called the Edwards Aquifer). The Edwards Outlier Aquifer is the highest in elevation and informally defined here to describe groundwater that occurs in the hydrologically discontinuous, isolated outcrops of Edwards Limestone on hilltops in and near GCSNA. The aquifer is unconfined, recharges through karst features and fractures in the limestone, and locally does not yield enough water to support water wells. Some of its water flows directly into the underlying upper Glen Rose, and some is discharged from seeps and small springs near the top of the upper Glen Rose where the Edwards Limestone is perched on poorly permeable beds.

The upper member of the Glen Rose is the sole unit of the Upper Trinity Aquifer. This aquifer is unconfined and locally recharged. Although the upper Glen Rose contains enough clay and marl beds to make it the lower aquiclude for much of the Edwards Aquifer, its outcrop exposes enough limestone and dolomite beds to absorb some recharge. Regionally, there is relatively little use or demand for the aquifer's groundwater because of its low yield and its contact with gypsiferous zones, which results in occasional high sulfate concentrations. Yet locally in the north Bexar County area, most privately owned wells tap upper Glen Rose water, especially since its upper $38 \mathrm{~m}$ are cavernous and yield larger volumes of water. In addition to wells, the Upper Trinity Aquifer also discharges through seeps and minor springs.

Significant but poorly quantified volumes of water also discharge from the upper Glen Rose into the Edwards Aquifer. This hydrologic connection was best demonstrated in northern Bexar County through a series of dye tracing studies (Johnson et al., 2010) roughly 20 $\mathrm{km}$ east of GCSNA.

The Edwards Aquifer is a complex hydrologic system which is divided into four zones: contributing or drainage, recharge, artesian or confined, and saline. The contributing zone is the upgradient non-Edwards Limestone area from which streams flow onto or cross the recharge zone where water enters the Edwards Aquifer. The recharge zone is defined by the exposure of Edwards Limestone within the Balcones Fault Zone. Most of GCSNA is within the recharge zone. The artesian zone is that area where the Edwards Limestone is down-faulted into the subsurface, and its groundwater is confined between upper and lower less permeable formations. The aquifer's largest springs occur where groundwater rises up fractures to discharge in stream valleys that intersect the potentiometric surface. The "bad water line" is the downgradient boundary of the artesian 
zone with the saline zone, where total dissolved solids in the groundwater exceed 1,000 mg/l. Groundwater flow in western Bexar County is complicated but generally down-dip southward, then eastward along strike.

\section{Caves and Karst}

Systematic transect surveys at GCSNA have revealed 37 open caves and 360 non-cave karst features, many of which seem likely to open into caves with some excavation (Miller, 2012). Most of the caves and karst features are developed in the Edwards Limestone as recharge features for the Edwards Aquifer. Some extend into the Glen Rose Formation. A few caves are phreatically formed and predate the modern aquifer, most notably Government Canyon Bat Cave which is the largest cave chamber in the county at about $90 \mathrm{~m}$ long by $20 \mathrm{~m}$ wide by $8 \mathrm{~m}$ high. While the Austin Chalk is cavernous elsewhere in Bexar County, no caves or notable karst features occur at GCSNA probably because the outcropping horizon is less permeable and soluble.

Caves at GCSNA are typically small and relatively shallow. Dancing Rattler Cave is the longest at $225 \mathrm{~m}$ and Lost Pothole the deepest at $23 \mathrm{~m}$. Similarly, sinkholes are small, typically $<2 \mathrm{~m}$ in diameter and $<0.3 \mathrm{~m}$ deep. Sinkholes are rare in the upper Glen Rose, especially solutionally-formed sinkholes, but one significant sinkhole collapse occurred within the unit following rainfall in Spring 2011. At $5 \mathrm{~m}$ by $3 \mathrm{~m}$ by $8 \mathrm{~m}$ deep, Turquoise Sink is the largest collapsed sinkhole in the county to occur in historic times.

While the karst features of GCSNA are topographically subdued, their collective karstic permeability is high. The Government Canyon stream bed is normally dry except where perched for short distances immediately downstream of springs. A few sections of the valley floor gently rise in the downstream direction as they pass areas of high fracture permeability. Monitoring of flows (unpublished data) show only water from the largest storm events flows off the Edward Aquifer recharge zone via that stream bed without being fully diverted into the aquifer.

\section{GCSNA Cave and Karst Biology}

The epigean fauna of GCSNA includes a diverse array of mammals, herpetofauna, and invertebrates. Birds are especially abundant with over 90 species identified, including the federally listed endangered Goldencheeked warbler and Black-capped vireo, that latter of which was first reported in 1972 but is seldom seen (Wiesema, 1972). This diversity is a direct result of Government Canyon's sheltered to open environment, its location at the junction of two major ecological zones, and especially due to the presence of perennial karst springs, which are not found in many other canyons and valleys along the Balcones Escarpment.

GCSNA's hypogean fauna is arguably more significant and proportionally diverse. Cave ecosystems, by their nature as food-poor environments, have lower species populations and diversity compared to surface ecosystems. But relative to many karst areas, the caves and karst features of GCSNA are biologically rich with 65 identified species, 15 of which are troglobites, 14 troglophiles, and at least an additional 53 species remaining to be identified. Of the troglobites, six invertebrates are federally listed as endangered species, occurring in 14 GCSNA caves, and one is endemic to GCSNA. While not endangered, three bat species are known in at least seven caves, with Government Canyon Bat Cave containing the largest bat colony in the county (Miller and Reddell, 2011).

\section{Cave and Karst Cultural Resources}

For thousands of years, Government Canyon has been an important natural thoroughfare through the rugged hills along the Balcones Escarpment in the San Antonio area. Unlike most canyons in the region that end steeply, Government Canyon maintains a gentle gradient from the base of the escarpment up to the fringe of the Edwards Plateau. Indians, Spaniards, US military, and ranchers used the canyon's natural trail, spring-fed water, wild game, and vegetation.

A number of archeological sites have been recorded in GCSNA (Dillehay, 1972). Most of these sites represent Native American encampments, one roughly estimated as representing several thousand years of regular occupation; 24 sites are eligible as State Archeological Landmarks. McNatt et al. (2000) provided an evaluation of prehistoric use of its southernmost area, and Greaves (2002) examined archeological features near parts of GCSNA's trail system, but a comprehensive archeological study of the entire property is needed in order to definitively determine the full extent to which Government Canyon was used by Native Americans and the nature of that use. Doubtless it served as a vital and reliable source of water, as well as for chert for 
tool-making, since chert is only found in the Edwards Limestone in the region. At least two caves are known to have served as human burial sites (Veni, 1994 and 1996). Also within the Natural Area is a historic structure, believed to have been built in 1883, referred to as the Zizelmann House. This stone and wood structure purportedly has seen use as a home, a stage coach stop, and in later years, a hunters' camp.

\section{GCSNA: A Model for Karst Management Partnerships for Land Acquisition and Protection}

In the 1850s, Government Canyon became an important route between San Antonio and military forts to the northwest. This use by government troops gave the canyon its name. In the $1880 \mathrm{~s}$, it became a busy stage coach route between the towns of San Antonio and Bandera, and along with surrounding areas, most of the canyon began to be consolidated under the ownership of the Hoffman family. The Hoffmans and their successors ranched the property for about 100 years.

In the 1970s, the San Antonio Ranch New Town Corporation purchased the ranch to build a community with a proposed population of more than 80,000 residents. They continued to lease most of the property for ranching but only developed the northeast corner along Highway 16. In the late $1980 \mathrm{~s}$, the corporation failed during the nationwide savings and loans collapse, and the property was taken over by the federal government's Resolution Trust Corporation (RTC).

RTC placed the property for auction, where it was nearly purchased again for development. However, it was saved through the action of the Government Canyon Coalition (GCC), a group of 45 civic and environmental organizations. The Government Canyon property encompassed much of the Government Canyon watershed over the karstic Edwards Aquifer recharge zone, the primary water supply for the region. Growth of the City of San Antonio onto the recharge zone had raised concerns about preserving the aquifer's quality and quantity (e.g. Kipp et al., 1993) and owning key portions of the recharge zone was seen by the GCC as an effective means of aquifer protection.

The GCC first sought to have the property purchased by the Texas Parks and Wildlife Department (TPWD), which lacked the funds. The City of San Antonio and Edwards Underwater Water District (EUWD; now reorganized as the Edwards Aquifer Authority) were approached, but the city did not see the value in owning parts of the recharge zone while EUWD saw the value but did not want to own and manage land. This impasse was breached when the GCC involved the Trust for Public Land (TPL). TPL got Government Canyon removed from the auction list and facilitated a deal for its purchase by TPWD. Since TPWD was short of funds, TPL and GCC convinced the City of San Antonio's San Antonio Water System and the EUWD to pay $75 \%$ ( $\$ 1.5$ million) of the purchase price, while TPWD maintained title and general management of the $19.09 \mathrm{~km}^{2}$ property. The property was designated as Government Canyon State Natural Area. See Freeman (1994) for a detailed history of the property up to the time of this acquisition.

The establishment of GCSNA served as a magnet to expand protection of the Government Canyon karst watershed, but also for the protection of its other natural and cultural assets. Figure 1 illustrates the acquisitions of properties surrounding the initial purchase as described in the following narrative.

On November 3, 1994, the US Department of Housing and Urban Development committed to adding 4.54 $\mathrm{km}^{2}$ to the property's northeast corner and was deeded to TPWD 15 months later. This tract was also part of San Antonio Ranch, but the presence of the endangered Golden-cheeked Warbler and the rugged terrain severely limited its capacity for development. TPWD made it a sanctuary for the Warbler, with no public access into that area during the months the birds are nesting.

The next acquisition occurred in 1999 through TPL which transferred ownership to TPWD of the 3.26$\mathrm{km}^{2}$ Davis Ranch-Upland Tract due to $\$ 1,581,000$ in donations from the San Antonio Water System and the Duncan, Frost, Kronkosky, Meadows, Morris Stafford, and USAA charitable foundations and trusts. The next year, TPL arranged the transfer of the $1.60-\mathrm{km}^{2}$ Gallagher Ranch to TPWD via additional independent fundraising efforts which covered all but $\$ 500,000$ of the total contract price, which TPWD paid with general operating funds. In 2002, TPWD purchased the 4.70- $\mathrm{km}^{2}$ Kallison Ranch from TPL for approximately $\$ 5$ million and sold a conservation easement to the City of San Antonio. TPWD used the funds from the city to qualify for a Land 


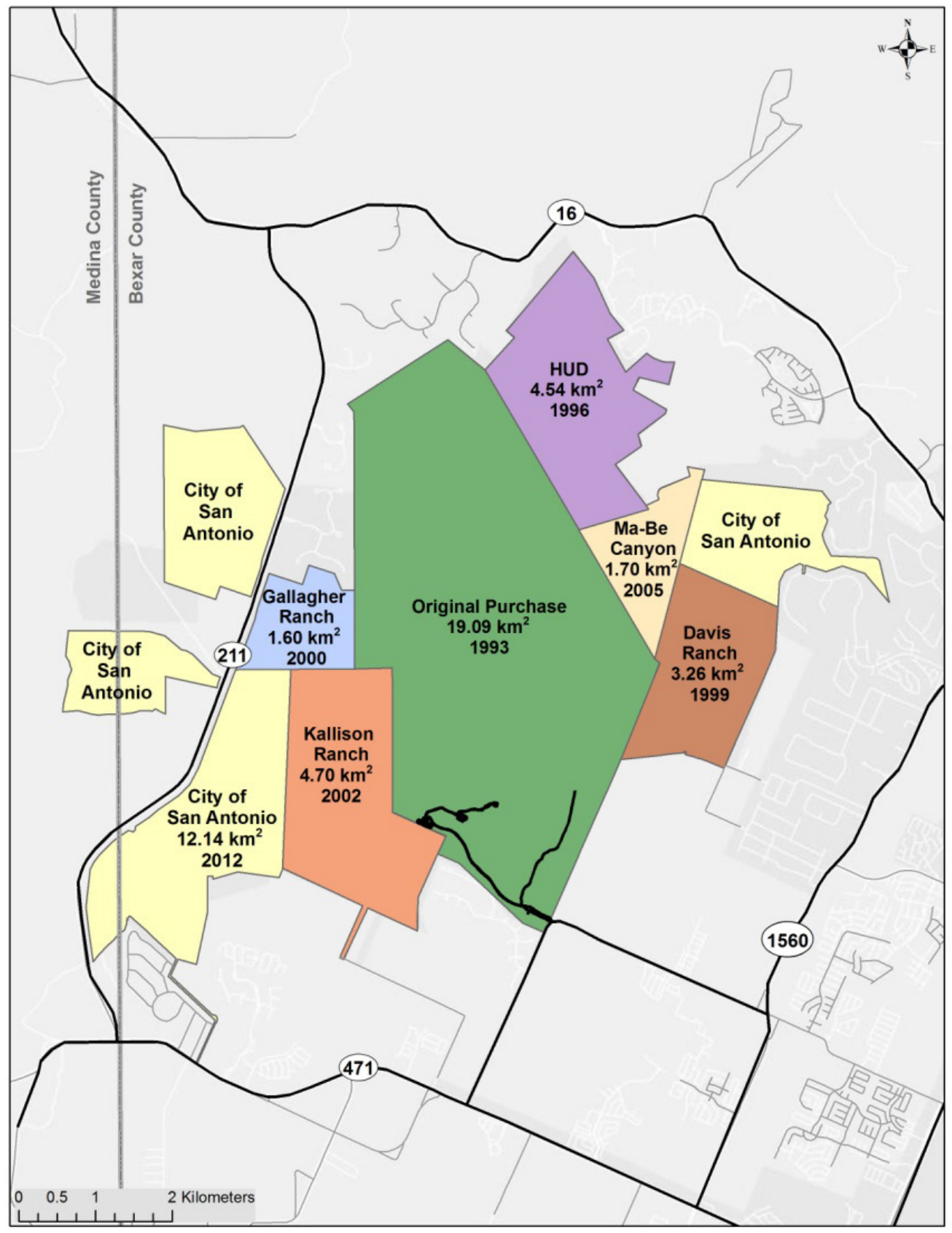

Figure 1. Properties acquired to expand GCSNA and protect the karstic Edwards Aquifer.

and Water Conservation Fund grant which covered 58\% of the purchase price.

This creative and cooperative development of funding was instrumental in heightening public awareness of the importance of GCSNA in protecting the Edwards Aquifer and its endangered species. So starting in 2001, San Antonio citizens passed the first of three sales tax increases that in total raised $\$ 220$ million to buy land to protect the Edwards Aquifer recharge zone and endangered species, and allow for limited recreation. By 2009, this tax initiative led to the purchase of four additional properties adjacent to GCSNA that totaled $12.14 \mathrm{~km}^{2}$. They are all in the process of being deeded to TPWD for management. During this time the 1.70 $\mathrm{km}^{2}$ Ma-Be Canyon was purchased and Ruth McCrary donated a small but environmentally important 0.01 $\mathrm{km}^{2}$ for similar aquifer and species protection. These acquisitions raised the total contiguous area of GCSNA (including two on the opposite side of Texas Highway 
211) from an initial $19.09 \mathrm{~km}^{2}$ to $47.04 \mathrm{~km}^{2}$, extending into neighboring Medina County, and protecting more than $41 \mathrm{~km}^{2}$ of the Edwards Aquifer recharge zone and its endangered species habitat, and about $62 \%$ of the Government Canyon watershed on the Edwards Aquifer recharge and contributing zones (Figure 2).

\section{Partnerships for Multidisciplinary Karst Management}

GCSNA was slow to open to the public. The core section of the property was acquired in 1993 but it was not opened to the general public until October 2005. The delay was not due to insufficient funding but from the TPWD mandate that the primary purpose of a "State Natural Area" is resource protection and management, with recreation being of secondary importance and must not adversely impact the natural area's resources. Therefore, before recreation and public access was possible, TPWD conducted inventories of its natural and cultural resources to determine the important scenic, educational, hazardous, and sensitive areas of the property. Surveys include studies of caves, plants, animals, history, and pre-history. Where possible, volunteers were used, and continue to be used to conduct

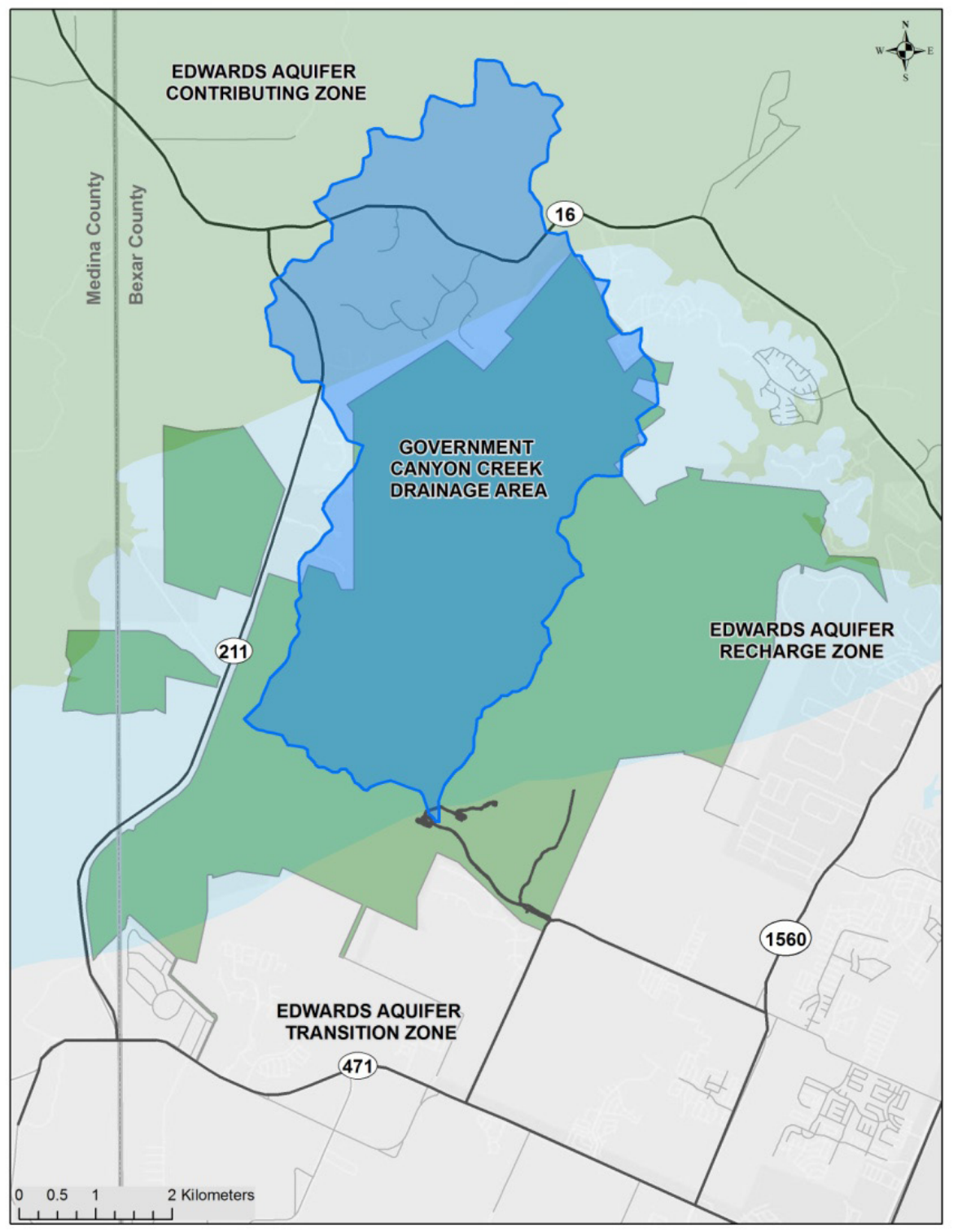

Figure 2. GCSNA boundaries and the Government Canyon drainage area relative to the Edwards Aquifer contributing, recharge, and transition zones. 
or assist with these surveys. The Government Canyon Karst Project alone has conducted 110 trips from August 1994 through October 2012 to survey, study, and restore or protect, where needed, GCSNA's cave and karst resources (Miller, 2012).

The focus for much of the resource work, especially before GCSNA opened publically, was through the Government Canyon Natural History Association (GCNHA). In 1995, GCC reorganized itself into GCNHA, a nonprofit corporation dedicated to organizing and managing support for the Natural Area. On November 15, 1996, a Memorandum of Agreement (MOA) between TPWD and GCNHA established a framework to cooperatively promote the preservation and protection of the natural and cultural resources of the natural area. Toward this end, GCNHA assisted TPWD in:

1. developing a management plan to ensure the protection and appropriate use of GCSNA;

2. working to preserve and protect the natural and cultural resources of GCSNA;

3. developing educational programs on the natural and cultural resources of GCSNA for the visiting public;

4. building a constituency of support for GCSNA; and

5. promoting volunteerism for GCSNA.

After GCSNA's public opening, GCNHA changed its name to the Friends of Government Canyon and as of October 2012 has logged over 200,000 volunteer hours in resource study, protection, management, and public education programs (Friends of Government Canyon, 2012).

In 1998, the Government Canyon Master Plan (TPWD, 1998) was adopted. It emphasized protection of the Edwards Aquifer, as well as the natural area's endangered and threatened species and cultural resources. Dictated by principle and enforced by deed restrictions, all development and new park facilities would be restricted to the southernmost sections that are off the Edward Aquifer recharge zone. The majority of GCSNA, which is over the recharge zone, currently has almost $68 \mathrm{~km}$ of multi-use trails; a few dirt roads are present only for emergencies, natural area maintenance, and research. These trails are only within the initially-purchased 19.09 $\mathrm{km}^{2}$ and the 4.54- $\mathrm{km}^{2}$ Housing and Urban Developmentacquired tract. Study of the more recently acquired properties is underway and their use will be determined accordingly when their resources are better identified and understood.

Most cave and karst research and management activity at GCSNA is unpublished, limited primarily to reports submitted to TPWD. The majority is through the Government Canyon Karst Project, but other works include stream flow and recharge monitoring by the US Geological Survey, as well as student and other independent research.

The most active karst management activity involves monitoring the populations of the endangered karst invertebrates and active management actions such as regular eradication of the non-native Red Imported Fire Ants (Solenopsis invicta) which predate upon the karst species. As a result of TPWD's proactive efforts through its Karst Management and Maintenance Plan and assistance by its volunteer partners, the US Fish and Wildlife Service determined that "management for the caves and the species in the Natural Area provides adequate special management considerations for the primary constituent elements, and consequently [habitat] units within the Natural Area that we proposed for [critical habitat] designation are not included" (USFWS, 2003). This determination provided GCSNA fewer constraints in its research and management activities, and may lead to continued support for future karst projects.

\section{Conclusions}

Government Canyon State Natural Area is a model for the protection and management of specific caves and karst areas through partnerships and creative financing for property acquisition, deed restriction, public education and tax-payer initiatives, and multidisciplinary research and management actions. The synergistic karst-related benefits are the protection of the quality and the quantity of recharge into the karstic Edwards Aquifer, the primary water supply for nearly 2 million people, and the simultaneous protection of habitat for six endangered karst species. Habitat protection for an endangered bird species that nests mostly in karstic canyons and easy access to a large natural karst environment which educates the citizens of Texas about karst are additional major benefits. Cultural resources, while rarely found in GCSNA caves, are generally not 
discussed publicly until funds can be allocated for their proper study and management.

GCSNA staff and volunteers understand the importance of karst and highlight it in their public education efforts. The GCSNA gift shop is named "Recharge" to stress the property's value to spiritual, ecological, and aquifer replenishment. And the attitude at GCSNA of waiting to understand their complicated resources and their complex relationships, before deciding how to manage them, should be applauded and followed in all karst areas.

\section{Acknowledgements}

This paper is a summary culmination of hundreds of people's efforts over more than two decades at GCSNA. My thanks go to all of the volunteers, partners, and the staff at TPWD for their support of my work there, and especially for their efforts to preserve, study, and protect this fabulous area. Specific thanks go to GCSNA Superintendent Chris Holm, GCSNA Administrative Assistant Carl Green, and TPWD GIS Specialist Jennifer Estes for their support with graphics and a critical review of the manuscript for accuracy and completeness. Additional thanks go to the staff of the National Cave and Karst Research Institute and reviewers of the Sinkhole Conference for their helpful suggestions.

\section{References}

Barnes, VE. 1983. Geologic atlas of Texas, San Antonio sheet. Austin (TX): Bureau of Economic Geology, The University of Texas.

Dillehay, TD. 1972. An initial archeological reconnaissance of areas to be affected by the San Antonio New Town, Bexar County, Texas. The University of Texas at Austin Research Report No. 13, Texas Archeological Salvage Project.

Freeman, MD. 1995. A history of Government Canyon State Property, Bexar County, Texas. Austin (TX): Texas Parks and Wildlife Department, unpublished report.

Friends of Government Canyon. About us [Internet]. 2012. San Antonio, Texas: Friends of Government Canyon [updated 2012 Oct; cited 2012 Oct 20]. Available from: http://www.friendsofgc.org/ aboutus.html

Greaves, RD, Mauldin RP, Tomka SA. 2002. An Archaeological Survey of Trail Locations in a Portion of Government Canyon State Natural Area, Bexar County, Texas. Volume 1: Project Summary, Survey Results, and Recommendations. Volume 2:
Site Descriptions and Supporting Documentation. Center for Archaeological Research Archaeological Survey Report, No. 329, The University of Texas at San Antonio.

Johnson, S, Schindel G, Veni G. 2010. Tracing groundwater flowpaths in the Edwards Aquifer Recharge Zone, Panther Springs Creek Basin, northern Bexar County, Texas. Edwards Aquifer Authority Report No. 10-01.

Kipp, GK., Farrington PT, Albach MJ. 1993. Urban development on the Edwards Aquifer recharge zone. Edwards Underground Water District Staff Report.

McNatt, L, Beceiro C, Freeman MD, Howard M, Tomka SA, Schuchert P, Ward CG. 2000. Archeological Survey and History of Government Canyon State Natural Area, Bexar County, Texas. Austin (TX): Cultural Resources Program, Texas Parks and Wildlife Department.

Miller, M. 2012. Government Canyon Karst Project Report \#101. Austin (TX): Texas Speleological Association, unpublished report.

Miller, M, Reddell J. 2011. Summary of biological collections and observations from caves at Government Canyon State Natural Area. Austin (TX): Texas Speleological Association, unpublished report.

Stein, WG., Ozuna GB. 1995. Geologic framework and hydrogeologic characteristics of the Edwards Aquifer recharge zone, Bexar County, Texas. US Geological Survey Water-Resources Investigations 95-4030.

Texas Parks and Wildlife Department. 1998. Government Canyon State Natural Area Master Plan, Texas Parks and Wildlife Department.

US Fish and Wildlife Service. 2003. Endangered and threatened wildlife and plants; Designation of critical habitat for seven Bexar County, TX, invertebrates species. Federal Register 68: 17156-17231.

Veni, G. 1994. Government Canyon Karst Project Report \#4. Austin (TX): Texas Speleological Association, unpublished report.

Veni, G. 1996. Government Canyon Karst Project Report \#12. Austin (TX): Texas Speleological Association, unpublished report. 